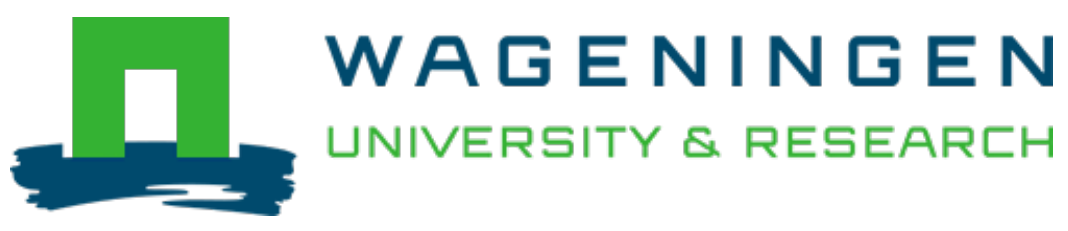

\title{
Integrating biodiversity conservation in wider landscape management : Necessity, implementation and evaluation
}

The Future of Agricultural Landscapes, Part I

Kleijn, David; Biesmeijer, Koos J.C.; Klaassen, Raymond H.G.; Oerlemans, Natasja; Raemakers, Ivo et al https://doi.org/10.1016/bs.aecr.2020.08.004

This article is made publicly available in the institutional repository of Wageningen University and Research, under the terms of article $25 \mathrm{fa}$ of the Dutch Copyright Act, also known as the Amendment Taverne. This has been done with explicit consent by the author.

Article 25 fa states that the author of a short scientific work funded either wholly or partially by Dutch public funds is entitled to make that work publicly available for no consideration following a reasonable period of time after the work was first published, provided that clear reference is made to the source of the first publication of the work.

This publication is distributed under The Association of Universities in the Netherlands (VSNU) 'Article $25 \mathrm{fa}$ implementation' project. In this project research outputs of researchers employed by Dutch Universities that comply with the legal requirements of Article $25 \mathrm{fa}$ of the Dutch Copyright Act are distributed online and free of cost or other barriers in institutional repositories. Research outputs are distributed six months after their first online publication in the original published version and with proper attribution to the source of the original publication.

You are permitted to download and use the publication for personal purposes. All rights remain with the author(s) and / or copyright owner(s) of this work. Any use of the publication or parts of it other than authorised under article $25 \mathrm{fa}$ of the Dutch Copyright act is prohibited. Wageningen University \& Research and the author(s) of this publication shall not be held responsible or liable for any damages resulting from your (re)use of this publication.

For questions regarding the public availability of this article please contact openscience.library@,wur.nl 


\title{
Integrating biodiversity conservation in wider landscape management: Necessity, implementation and evaluation
}

\author{
David Kleijn $^{a}, *$, Koos J.C. Biesmeijer ${ }^{\mathrm{b}, c}$, Raymond H.G. Klaassen ${ }^{\mathrm{d}}$, \\ Natasja Oerlemans ${ }^{\mathrm{e}}$, Ivo Raemakers ${ }^{\mathrm{f}}$, Jeroen Scheper ${ }^{\mathrm{a}}$, and \\ Louise E.M. Vet ${ }^{\text {g,h }}$ \\ ${ }^{\text {a} P l a n t ~ E c o l o g y ~ \& ~ N a t u r e ~ C o n s e r v a t i o n ~ G r o u p, ~ W a g e n i n g e n ~ U n i v e r s i t y, ~ W a g e n i n g e n, ~ T h e ~ N e t h e r l a n d s ~}$ \\ ${ }^{\mathrm{b}}$ Naturalis Biodiversity Center, Leiden, The Netherlands \\ ${ }^{\mathrm{c}}$ Institute for Environmental Sciences, Leiden University, Leiden, The Netherlands \\ ${ }^{\mathrm{d}}$ Conservation Ecology Group, Groningen Institute for Evolutionary Life Sciences, University of Groningen, \\ Groningen, The Netherlands \\ ${ }^{\mathrm{e}}$ World Wide Fund for Nature Netherlands, Zeist, The Netherlands \\ ${ }^{f}$ Citizen Scientist, Gronsveld, The Netherlands \\ ${ }^{\mathrm{g}}$ Department of Terrestrial Ecology, Netherlands Institute of Ecology (NIOO-KNAW), Wageningen, \\ The Netherlands \\ ${ }^{\mathrm{h}}$ Laboratory of Entomology, Wageningen University, Wageningen, The Netherlands \\ *Corresponding author: e-mail address: David.Kleijn@wur.nl
}

\section{Contents}

1. Introduction

2. Limitations of current biodiversity conservation approaches 130

2.1 Management constraints of current conservation approaches 130

2.2 Socio-economic constraints of current conservation approaches 133

3. Connecting protected areas, farmland and public space 135

3.1 Selecting areas for landscape-level collaborative biodiversity conservation 137

3.2 Key Performance Indicators for biodiversity conservation 141

$\begin{array}{ll}\text { 3.3 Monitoring impact on biodiversity } & 145\end{array}$

4. Conclusions 148

Acknowledgements 149

References 149

\begin{abstract}
Current conservation instruments, which for most species rely heavily on protected areas, are insufficient to halt biodiversity loss. Conservation initiatives in the wider landscape surrounding protected areas are needed to achieve the impact required for reversing negative biodiversity trends. Focussing on intensively used north-western European landscapes, we present a landscape-level conservation approach that
\end{abstract}


coordinates, integrates and evaluates conservation management by different stakeholders in protected areas, farmland and public space. The starting point is the set of environmental conditions or the habitat characteristics that is needed to realize stable or positive biodiversity trends. Such sets are captured in Key Performance Indicators (KPIs) that can be quantified easily over large areas. Integrated monitoring and evaluation of the relationships between KPIs, management and biodiversity need to be used to validate initial assumptions and continuously improve conservation effectiveness. Evaluation relies on trend monitoring in areas with and without conservation management and extrapolations to landscape-level biodiversity trends based on the total area on which conservation is being implemented. The relationships between biodiversity and KPIs can subsequently be used to develop biodiversity-based business models and to inspire and help stakeholders within and outside these focal areas to actively join the initiative.

\section{Introduction}

Almost 50 years after the adoption of the Ramsar Convention on Wetlands, the first global convention targeting the protection of nature, and more than 25 years after the Convention of Biological Diversity entered into force, biodiversity continues to decline at unprecedented rates (Pimm et al., 2014; WWF, 2016). World leaders have failed to meet their initial target to achieve a significant reduction in the rate of biodiversity loss by 2010 (Butchart et al., 2010). Despite accelerating policy and management responses to the biodiversity crisis, they are not likely to meet their renewed commitments either (IPBES, 2019; Tittensor et al., 2014).

Current efforts, conservation policies and instruments are primarily based on designating biodiversity refuges in the form of nature reserves or protected areas, i.e. clearly defined areas dedicated and managed for the long-term conservation of nature and associated ecosystem services (Day et al., 2019). This approach has resulted in important conservation successes. For example, designation of protected areas reduces species extinction risk (Butchart et al., 2012) and birds listed on Annex I of the EU's Birds Directive have more positive population trends than non-Annex I species (Donald et al., 2007; Sanderson et al., 2016). Nevertheless, protected areas regularly fail to sustainably conserve biodiversity (Dahler et al., 2019; Hallmann et al., 2017; Virkkala et al., 2018) and have not been able to prevent around one million animal and plant species from being threatened with extinction (IPBES, 2019).

One of the strongest drivers of biodiversity decline is agriculture (IPBES, 2019; Tilman et al., 2017). Agricultural expansion results in habitat 
destruction and adversely affects biodiversity in remaining non-agricultural habitats, such as protected areas, through fragmentation and isolation effects. Intensification of farming practices may additionally result in habitat degradation, for example through emissions of agrochemicals or changes in hydrology. Given the typical underfunding of protected areas (Bruner et al., 2004) and the limited scope for their expansion there is a growing recognition that halting overall biodiversity loss requires the integration of farmland into biodiversity conservation programmes (Donald and Evans, 2006; Driscoll et al., 2013; Grass et al., in press; Kremen and Merenlender, 2018; Mendenhall et al., 2016; Xu et al., 2017). The big question is how conservation of biodiversity can effectively be integrated into the management of the habitat mosaic that typically makes up an agricultural landscape. Some 40 years of actively promoting farmland wildlife in Europe suggests that it is difficult to enhance or conserve biodiversity on agricultural land even when farmers are being subsidized to do this (Kleijn et al., 2011). The agricultural sector is also reluctant to embrace management practices that can enhance biodiversity-based ecosystem services, such as pollination, pest control or nutrient cycling, that can support agricultural production and partially replace environmentally harmful external inputs (Kleijn et al., 2019). Providing publicly funded conservation instruments or demonstrating the evidence of the benefits of biodiversitybased alternatives have so far proven insufficient for the internalisation of biodiversity management into farm businesses.

Here we present and discuss an approach that could overcome some of the main shortcomings of current conservation instruments. Our approach has been developed with the densely populated human-dominated agricultural landscapes of Europe in mind. There, protected areas are generally small, with $77 \%$ of the Nationally Protected Areas being less than 100 ha (EEA, 2012; Gaston et al., 2008). This makes them particularly vulnerable to the effects of surrounding land-use, perhaps more so than the often larger protected areas on other continents. Furthermore, a significant proportion of biodiversity in Europe has co-evolved with agricultural management since the first European settlements about 7000-9000 years ago started gradually changing the landscapes (Batary et al., 2015; Poschlod et al., 2005). Due to recent accelerating agricultural intensification on productive lands and abandonment of agriculturally marginal farmland, species that for centuries found a suitable niche on farmland have become some of the most threatened species groups in Europe (Gregory et al., 2008). Species groups including farmland birds, butterflies and orchids have now become the 
objective of conservation efforts on farmland as well as in protected areas (Smart et al., 2014). Although our approach is tailored to Europe, we think some of its principles are also relevant beyond this continent. Worldwide only $5 \%$ of the world's land remains unaffected by humans (Kennedy et al., 2019), the size of natural areas that individual species can occupy continues to decrease (Tilman et al., 2017), even in large protected areas wildlife is influenced by people in surrounding communities (Packer et al., 2013) and also on other continents many species can be found inhabiting both protected areas and farmland or even specializing on farmland habitats (Mendenhall et al., 2016).

We start by giving an overview of key ecological and socio-economic shortcomings that limit the effectiveness of current conservation approaches. We then outline promising avenues to address these issues with the objective of improving the effectiveness of biodiversity conservation. We specifically focus on issues of scale and landscape context as these are pivotal factors determining biodiversity levels and population persistence, particularly in human-dominated landscapes (Seibold et al., 2019; Tscharntke et al., 2012; WWF, 2016). We discuss key aspects that should be considered when implementing such an alternative conservation approach in practice. Because conservation initiatives are invariably constrained by cost issues (McCarthy et al., 2012), we propose an approach to link conservation efforts to business models so that economic aspects of conservation become less of a barrier to land-owners and possibly even an incentive. Finally, we outline how the ecological effects of this approach could be monitored and evaluated with the objective to learn and improve.

\section{Limitations of current biodiversity conservation approaches}

\subsection{Management constraints of current conservation approaches}

Conservation initiatives generally prescribe or restrict land-use in a designated area, for example by prohibiting hunting or harvesting, specifying whether and how much livestock can graze, and defining to what extent commercial or residential areas can be developed and where and when people are allowed to recreate. However, conservation initiatives rarely influence land-use in the areas surrounding the sites with conservation management. In the 17 th and 18 th century, when the first protected areas were designated, this was rarely relevant because the impact of human land-use 
outside protected areas on the environmental conditions within the protected areas was limited, and contrasts in land-use within and outside protected areas were initially not very large. However, increasing human population growth and economic development has resulted in drastic changes outside protected area borders. To increase agricultural productivity, land in between protected areas has been cleared, drained, seeded, levelled, fertilized and irrigated (Liu et al., 2015). Agricultural land, in turn, has been being taken for urban and other artificial land development. In the period 2000-2006, over $1000 \mathrm{~km}^{2}$ of farmland, forest and semi-natural habitat in the European Union were converted annually to housing, services and recreation, industrial and commercial sites, transport networks and infrastructures, mines, quarries and waste dumpsites and construction (EEA, 2019). These developments steadily isolated protected areas by removing resources and habitats, and increasing the inhospitability of the landscape matrix for wildlife in between the remaining refuges (Ricketts, 2001; Watling et al., 2011).

Apart from isolation and fragmentation effects, biodiversity in protected areas is increasingly influenced by activities and ecological processes occurring outside protected areas (DeFries et al., 2010; Kremen and Merenlender, 2018). Examples include: deposition of nitrogen originating from farming; traffic and industry threatening the persistence of endangered plant species in protected areas (Kleijn et al., 2008; Wamelink et al., 2013); altered hydrological regimes due to irrigation or drainage of farmland causing the decline of threatened birds in coastal wetlands (Robledano et al., 2010); presence of roads causing mammals to avoid parts of protected areas (D'Amico et al., 2016) or facilitating the spread of invasive species that adversely affect native species (Foxcroft et al., 2011); windborne pesticides that are contributing to amphibian decline in pristine locations (Davidson and Knapp, 2007); human debris entrapping snakes in nature parks (Ortega and Zaidan, 2009). The adverse effects of human activities on biodiversity in protected areas have been observed at a wide range of scales and on species groups occupying all trophic levels. Without conservation action in surrounding areas, part of the positive effects of protected areas on biodiversity will be counteracted.

Policy instruments and initiatives that aim to integrate conservation of biodiversity in farm management already exist, especially in parts of the world with intensive farming. European agri-environment schemes are perhaps the best known example, but the United States has similar programmes, including the Conservation Reserve Program, the Environmental States 
Quality Incentives Program, and the Wetlands Reserve Program (Lambert et al., 2007). Particularly in Europe, where public spending on agrienvironment schemes often exceeds budgets available for biodiversity conservation through other routes (Batary et al., 2015), there is a wealth of studies examining the effectiveness of agri-environment schemes and how this is influenced by a range of different factors such as the proportion of semi-natural habitat in the landscape (Batary et al., 2011; Scheper et al., 2013) or the distance to nearest protected area (Kohler et al., 2008; Leng et al., 2009). Amongst other things, these studies suggest that implementation of agri-environment schemes is generally poorly aligned with conservation in protected areas, even though there is often overlap between the species targeted by the two instruments and evidence that combining site protection and agri-environmental management is more effective than implementing these two instruments separately (Smart et al., 2014). Appeals to enhance the synergy between the two instruments to increase the overall effectiveness of biodiversity conservation have been made for quite some time (Donald and Evans, 2006) and, in fact, implementing agri-environment schemes in buffer zones around protected areas was one of the founding principles of the first Dutch agri-environment schemes in 1975 (Meijer, 1975). Benefits would include buffering of protected areas against emissions of agrochemicals from farmland (Rasmussen et al., 2011) and improving connectedness of protected areas by enhancing the quality of the agricultural matrix (Brown et al., in press; Donald and Evans, 2006), as will enhancing the effectiveness of agri-environment schemes because protected areas can provide source populations to recolonize farmland (Leng et al., 2009). In the Netherlands, low uptake of the very first agri-environment schemes by farmers in areas bordering protected areas later led policy makers to abandon this requirement, which disconnected conservation in protected areas from nearby farmland. During the last decade, the disconnect has increased even further because of a shift in the objectives of biodiversity conservation in European farmland. Instead of aiming to conserve threatened and declining farmland species, objectives are increasingly shifting towards enhancing functional biodiversity for the delivery of ecosystem services that can support agricultural production (Krimmer et al., 2019; Tschumi et al., 2015; Van Vooren et al., 2018; Warner et al., 2017). This may result in conservation management on farmland being implemented in intensively farmed structurally simple landscapes because this is where ecosystem service enhancement is required (Kleijn et al., 2011), while protected areas are mostly located in extensively farmed structurally complex landscapes that still hold most of a country's biodiversity. 
Another limitation of current biodiversity conservation schemes is that a significant part of the landscape is ignored. Public space, such as roadside verges, stream or river banks, railway embankments, city parks and power lines often consists of semi-natural habitat and together comprises a significant proportion of the non-productive landscape. For example, the area occupied by roadside verges alone fluctuates around $1 \%$ of the total surface area in a range of European countries (based on Wojcik and Buchmann, 2012). In many parts of the world these habitats support important populations of a wide range of species groups including endangered ones (Confer and Pascoe, 2003; Gardiner et al., 2018; Heneberg et al., 2017). Nevertheless, management of public space is rarely included in biodiversity conservation programmes or strategies. Management is typically geared towards supporting their main function in the most cost-effective way, although occasionally conservation is an additional objective (Gardiner et al., 2018). In Europe, upkeep of public space is generally done by local or regional authorities paid from public funds. This could, in principle, make implementing conservation in public space much more cost-effective than on agricultural land because environmental conditions are generally much more favourable and land-owners do not have to be compensated for loss-of-income. Including public space in conservation strategies could therefore significantly enhance the flexibility and effectiveness of regional or national conservation programmes.

\subsection{Socio-economic constraints of current conservation approaches}

Biodiversity conservation currently operates largely in isolation from other processes and developments that shape the composition and land-use of landscapes. Ironically, many socio-economic activities that benefit significantly from biodiversity often cause a further decline of wild species of plants and animals (Vanbergen et al., 2020). For example, production of many crops is enhanced by insect pollination (Garibaldi et al., 2013), yet many practices to enhance agricultural production, such as removal of seminatural habitat or pesticide applications, result in loss of wild pollinators so that in many areas pollination is now the factor limiting growth in crop production (Deguines et al., 2014; Fijen et al., 2020). Proximity of attractive natural areas increases Dutch house prices by as much as 16\% (Daams et al., 2016), but urban expansion is a key driver of biodiversity loss (Seto et al., 2012). Access to natural areas is positively related to mental health (Bratman et al., 2015) and people prefer to recreate in quiet green natural places (de Vries et al., 2013), but recreational activities often adversely affect 
wildlife (Holm and Laursen, 2009). Approaches can be developed that allow for more synergies between human land-use and biodiversity but under the current economic paradigm they are generally more costly economically so that in the short term they are not widely adopted (Iverson et al., 2019). Mainstream land-use is driven by short-term cost-effectiveness and economies of size which generally results in overexploitation, agricultural expansion and urban sprawl to the detriment of biodiversity and the environment (Duffy, 2009; Polasky et al., 2011). These counterproductive developments are caused by a poor integration of biodiversity into policy and decision frameworks of sectors that may impact negatively on biodiversity (Pe'er et al., 2017; Rands et al., 2010; Runhaar et al., 2014). This is partly because biodiversity is a public good that is poorly captured by markets because it lacks monetary value (Turner and Daily, 2008), which may also explain the absence of biodiversity in business models of most banks, agrochemical and seed companies, agricultural inputs suppliers and food retailers that have an indirect, but major impact on day-to-day management of the landscape. Significant progress has been made in the valuation of public goods (Daily et al., 2009; Turner and Daily, 2008) but payment for ecosystem services is yet to become mainstream in biodiversity conservation. Economic incentives by themselves are also unlikely to transform local cultural, ethical and behavioural traits towards environmental stewardship (Turner and Daily, 2008), as exemplified in Europe by the low effectiveness of many agri-environment schemes and payment for ecosystem services avant la lettre, in enhancing biodiversity (Kleijn et al., 2006). Economic incentives for biodiversity conservation may even weaken intrinsic motivation for conservation (Rode et al., 2015). For example, Garcia-Amado et al. (2013) found that farmers receiving payment for ecosystem services tended to show more appreciation for the utilitarian and monetary aspects of conservation than farmers involved in projects based on adaptive management, education and technical assistance. Furthermore, support for the intrinsic and culturally based principles of conservation waned with the time that farmers had been receiving payment for ecosystem services. Thus, some care should be taken to ensure that the right economic triggers are being targeted.

Another factor that limits the effectiveness of current conservation instruments is that they are mostly top-down and it is questionable whether they are supported by the majority of the local communities in areas where they are being implemented. Lack of support by the people who are dealing with the consequences of conservation instruments may result in lack of ownership, which in turn may result in activities in and around conservation 
sites that are counterproductive to the conservation objectives. It may even result in a breakdown of support for nature conservation in general. For example, the Netherlands has been considered one of the leading nations in European nature conservation policy. It had played an important role in the development of a common European nature policy (Van den Top and Van der Zouwen, 2002). After national elections in 2010, though, many aspects of Dutch nature conservation policy that had been firmly institutionalized were suddenly challenged. Policy views on the type of nature worthy of protection changed significantly and budgets for nature conservation were cut by $70 \%$ (Buijs et al., 2014); considerably more than in almost any other sector. These changes were implemented without any public outcry. To ensure long-lasting support by the general public, who indirectly pay for conservation through their taxes, it is therefore important that top-down conservation is integrated with bottom-up conservation practice that is of relevance to local communities, such as generation of income or status (Abrams et al., 2009).

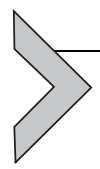

\section{Connecting protected areas, farmland and public space}

The key limitations of mainstream biodiversity conservation indicate that the effectiveness and impacts of conservation could be enhanced by coordinating and integrating conservation efforts in protected areas, on farmland and in public spaces. Such an integration would allow for the design of conservation management strategies at the landscape scale, the scale at which key environmental processes determining habitat quality, such as local hydrology or emissions of agrochemicals, can be effectively manipulated. It would help in realizing the amount, combination and configuration of habitats that are needed to support viable populations. Conservation approaches that include protected areas, farmland and public space increase the degrees of freedom in the design of effective conservation strategies (Fig. 1).

In many regions in Europe, but probably also elsewhere, integrative landscape-level approaches may be the best way to realize areas of high quality habitat that are sufficiently large and diverse for maintaining viable populations of target species. This would be very difficult to achieve by means of protected areas or agri-environment schemes as the sole conservation tool. Integrated landscape-level conservation management requires collaborative approaches. Because people and institutions with different 


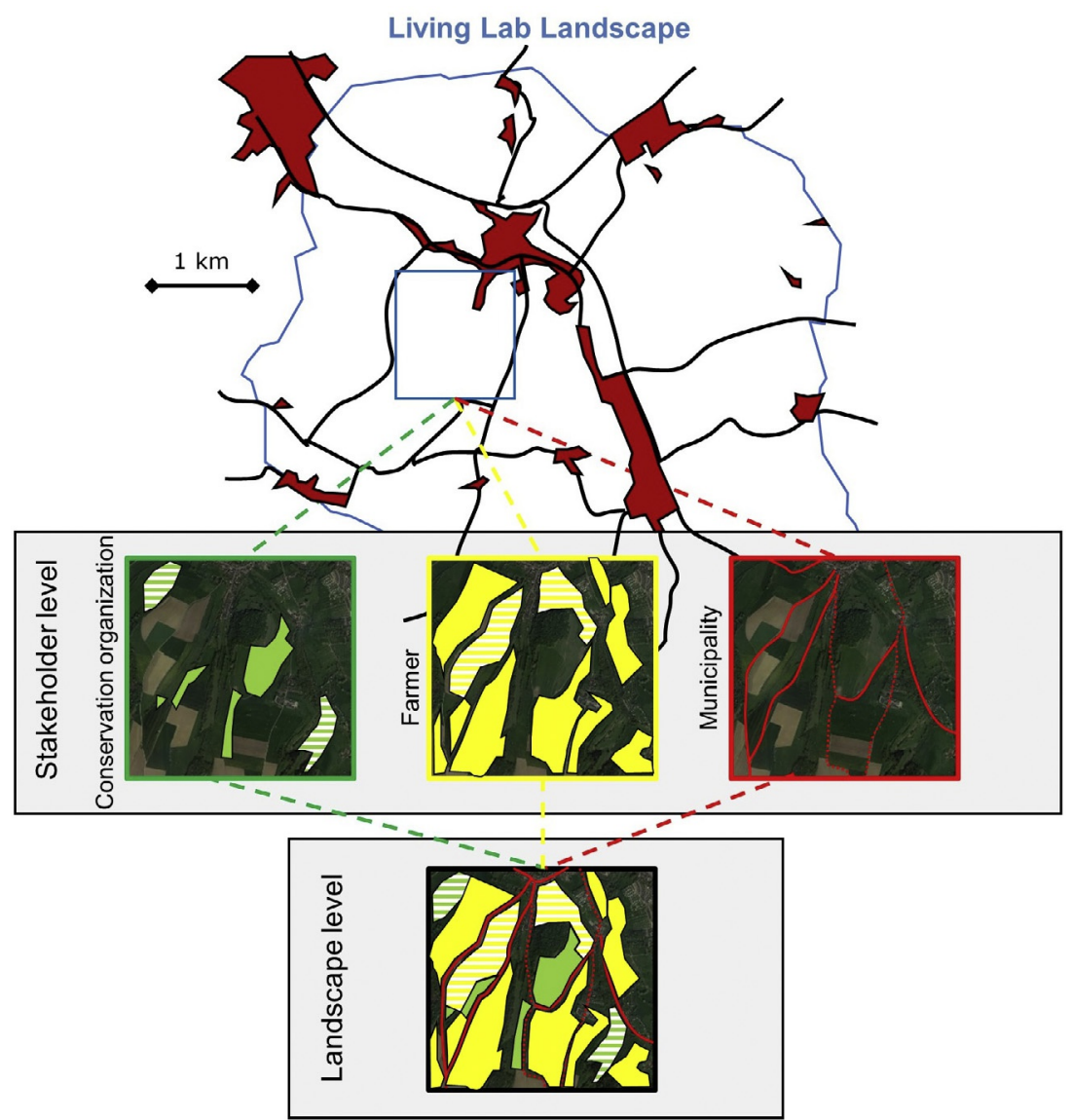

Fig. 1 A graphical illustration of the potential of landscape-level multi-stakeholder approaches to realize high density conservation efforts. Individual stakeholders can often optimize management on only a small proportion of their land (shaded areas). Targeting individual stakeholders would therefore generally result in fragmented and low density conservation efforts at the landscape scale. Targeting multiple stakeholders at the landscape-level makes it possible to achieve a connected network of high quality habitats.

backgrounds have to be motivated to work together, such initiatives need to be supported by local communities, they need to be backed by regulations and policies and any associated costs need, at the very least, to be compensated by additional sources of income. Collaborative conservation has been implemented since at least the 1950s focussing initially on the sustainable management of water resources (Koontz et al., 2020). Its popularity has increased since the year 2000 and it is now increasingly proposed as an 
approach to make mainstream biodiversity conservation more effective (McKenzie et al., 2013; Redpath et al., 2017; Sayer et al., 2013). The potential or necessity of large-scale conservation approaches that consider landscape context and that include participation of relevant stakeholders has been highlighted in many studies and by many authors (e.g. Abrams et al., 2009; Gonthier et al., 2014; Ritchie and Johnson, 2009; Sayer et al., 2013; Seibold et al., 2019). Concrete examples of how to implement such approaches and especially how their effects on biodiversity can be evaluated remain scarce (Koontz et al., 2020; Sayer et al., 2017).

Below we outline a landscape-level collaborative approach that was developed by a broad societal initiative to restore biodiversity throughout the Netherlands: the Delta Plan for Biodiversity Recovery (Anonymous, 2018). Leading stakeholders in the initiative include the main agricultural bank in the Netherlands, a retail organization, an agricultural input supplier, farmer organisations, scientists and environmental and nature conservation organisations. The Delta Plan identifies five success factors that make it simple and attractive for land managers to contribute to the restoration of biodiversity: (1) shared values; (2) development of biodiversity-based business models; (3) incentivizing and consistent laws and regulations; (4) knowledge and innovation; and, (5) collaboration with all regional land users. The landscape-level collaborative conservation approach was developed: (i) to evaluate whether the changes incurred by this societal initiative will be sufficient to bend the curve and achieve an increase in biodiversity; (ii) to learn and continuously improve efforts until positive biodiversity trends have been achieved; and, (iii) to inspire and help stakeholders within and outside these focal areas to join and participate in the initiative. The key features that distinguish it from previous landscape-level collaborative approaches are that it relies heavily on an evidence-based 'learning by doing' approach in combination with Key Performance Indicators (KPIs) that can be used as a basis for societal or economic triggers and to extrapolate effects of local management to larger spatial scales (Fig. 2; see Sections 3.2 and 3.3). Starting in 2021, this approach will be implemented in at least three landscapes in the Netherlands.

\subsection{Selecting areas for landscape-level collaborative biodiversity conservation}

The selection of specific areas for landscape-level collaborative approaches will benefit from a careful consideration of three interrelated issues: the primary species group or groups targeted, the composition and size of the 


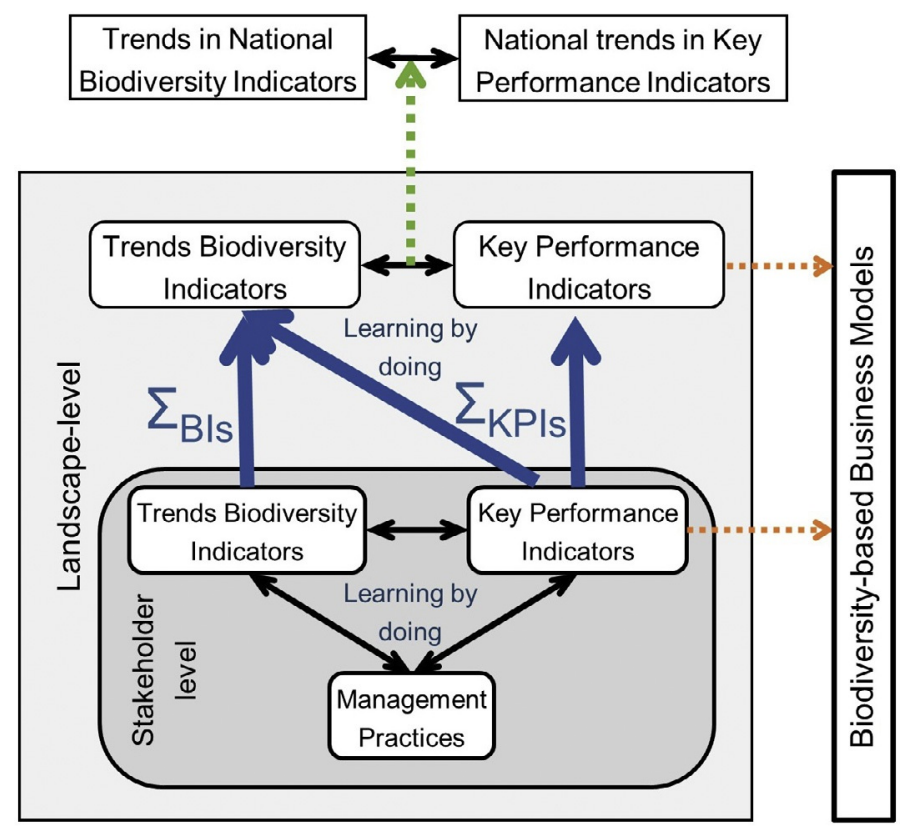

Fig. 2 The relations between conservation management and trends in biodiversity and Key Performance Indicators (KPIs) at three spatial scales. KPIs describe the quantity and quality of habitat or the state of the environmental conditions that has been achieved by management. Ideally KPIs are easily measurable and can be quantified at large spatial scales, which is generally not possible for biodiversity indicators. The relationship between KPIs and biodiversity indicators at the landscape-level can then be used to understand the contribution of conservation management to trends in existing national biodiversity indicators such as breeding birds and butterflies (Thomas, 2005; Van Strien et al., 2001; green dashed arrow). KPI achievements can be the basis for biodiversitybased business models (orange dashed arrows).

landscape needed by these species groups, and the organizations and people who manage the land and whose activities critically affect conservation outcomes. A threatened species group can be a logical starting point for selecting areas, which are then typically concentrated around population refugia. Initiatives can also start with the people involved, for example when stakeholder groups are present that are highly motivated to lead conservation initiatives.

\subsubsection{Species groups}

Conservation approaches should address the key population dynamical bottlenecks of the target species groups, but should do more than solely 
removing individual conservation threats as this may not result in sustainable solutions in the long run (Plard et al., 2020; Vogels et al., 2017). The aim should be to restore ecosystems that contain all resources that are needed for the species groups to successfully reproduce at rates sufficient for stable or positive population growth. The target species groups then become indicative of healthy and robust ecosystems. Generally targeting ecosystem health and restoration of natural processes (Perino et al., 2019), without a clear species group in mind for which the system is restored, could be counterproductive in human-dominated landscapes. Reserves are typically small and landscapes no longer subjected to extreme conditions that remove dominant climax species (e.g. long-term flooding or large-scale burning). Ecosystems are therefore no longer reset to early-successional stages by environmental dynamics and natural succession may drive ecosystem composition in the same direction everywhere. This could strengthen the ongoing process of biotic homogenization that is currently observed in north-western Europe (Nielsen et al., 2019; Van Turnhout et al., 2007). Targeting species groups may help create support and engage the general public in biodiversity conservation. Choosing a charismatic species group can help enrol actors in a broad network across diverse organizational boundaries as, in contrast to biodiversity in general, it gives them something to identify with (Gustafsson et al., 2015).

\subsubsection{Landscape composition and size}

Many studies highlight the importance of landscape composition for supporting diverse and abundant communities of species and their associated ecosystem services (e.g. Heath and Long, 2019; Kennedy et al., 2013; Kleijn et al., 2019; Shackelford et al., 2013; Steffan-Dewenter et al., 2002). However, we know much less about how much and which types of habitats need to be present in a landscape at what spatial scale to sustainably maintain viable populations. Most landscapes are a mosaic of suitable and unsuitable habitats and individuals often move within a network of different types of habitats to fulfil all requirements for completing their life cycle (Hagen et al., 2012; Osborne et al., 1999). Based on the selected species groups an assessment can be made as to which habitats in the landscape provide important resources and how their quality can be improved. Selecting areas that generally consist of the same landscape types and that are ecologically coherent has the advantage of limiting the number of different habitat types, which makes it easier to design a simple and consistent set of conservation measures for the entire landscape. Targeting some species groups 
automatically selects ecologically coherent areas. For example, grassland breeding waders are almost exclusively restricted to open wet grassland or peatland areas. The selected areas should be sufficiently large to be able to sustain viable populations of the key target species groups. Ideally this is based on information about minimum viable population size (Pe'er et al., 2014), habitat size, habitat quality, habitat isolation (Binzenhofer et al., 2008) and inter-patch dispersal (Vanden Broeck et al., 2017) and ultimately minimum area requirements.

However, this information is unavailable for most species. For example, Pe'er et al. (2014) reviewed the literature on studies that estimated minimum viable population size and found only 11 empirical studies providing occupancy-based estimates of the minimum area requirements, almost all of them on birds. Minimum area requirements generally increase with mobility of the target species group (Pe'er et al., 2014). For example, plant populations can persists for thousands of years on a few square metres (Steinger et al., 1996) while the estimated minimum area requirements of giant panda is $115 \mathrm{~km}^{2}$ (Qing et al., 2016). The size of the area that is required for effective landscape-level conservation approaches therefore is not fixed but should match the requirements of the target species groups. Until better data becomes available, areas will often need to be selected based on expert judgement and pragmatism. For example, the landscapelevel collaborative initiative in the area depicted in Fig. 1 targets bumblebee conservation and was selected based on expert judgement. It measures approximately $30 \mathrm{~km}^{2}$ which, based on estimated colony densities by Knight et al. (2005), could host 780-3510 colonies depending on species.

\subsubsection{Social coherence and socio-economic aspects}

From a social coherence perspective selected areas shouldn't be too large as this may result in loss of landscape coherence and with it their unique identity. Familiarity with the landscapes in which people grew up contributes to the development of a sense of place that may help enlist people in local nature conservation management (Bott et al., 2003). Furthermore, because it is easier to develop trustful relationships with people with the same backgrounds (Purdue, 2001) collaboration between stakeholder communities may be more difficult if areas become too large. Presence of social leaders or champions is important as they play pivotal roles in getting new paradigms in landscape management accepted and adopted in local communities (Purdue, 2001). Strong leadership has in fact been found to be the key contributing attribute to success in environmental initiatives (Gutierrez et al., 2011; 
Stobbelaar et al., 2018). It is unlikely that all stakeholders in a landscape will participate (and this can be used in evaluation studies for the selection of control areas, see below) but it is important that a minimum proportion of stakeholders takes part to realize the estimated minimum area of improved habitat required for increasing population sizes by the target species groups. In this process, the role of social leaders is particularly important.

\subsection{Key Performance Indicators for biodiversity conservation}

In Europe, nature conservation generally uses management prescriptions to try to achieve the desired outcomes. However, just prescribing management does not guarantee that habitat quality will be sufficiently enhanced as many factors may interfere with the management outcome. Ideally, management prescriptions are based on scientific evidence that this type of management has a high likelihood of producing biodiversity benefits. In reality, management is often based on tradition, common sense, personal experience or information from colleagues, all of which may reduce effectiveness (Sutherland et al., 2004). Even evidence-based management does not always ensure effective nature conservation as it is difficult to extract generalisable management guidelines that can work for individual locations from systematic reviews drawn from a wide geographic range (Cook et al., 2013). In a different context, outcomes may be different and management may fail to provide the conditions required to enhance biodiversity. For instance, wildflowers may fail to establish after sowing or may disappear over time due to competition with grasses (Pywell et al., 2003). Additionally, management prescriptions generally do not specify the area that should be covered to achieve a conservation outcome. A significant increase in species richness or abundance on sites with conservation management is often perceived as an indication of conservation success (e.g. Tuck et al., 2014) but may not represent the improvement required to maintain stable or increasing populations or biodiversity trends of the focal species (Baker et al., 2012; Schekkerman et al., 2008).

Key Performance Indicators can be used to describe the environmental conditions or the habitat characteristics that need to be achieved to realize stable or positive biodiversity trends. Rather than a change in management that just contributes to habitat improvement, KPIs describe the end result of management and are characterized by a certain quantity and quality of environmental variables (Table 1; Fig. 2). The improvement lies in the fact that 
Table 1 Examples of Key Performance Indicators (KPIs).

Key

$\begin{array}{ll}\begin{array}{l}\text { performance } \\ \text { indicator }\end{array} & \text { Main land } \\ \text { manager group References }\end{array}$

Biodiversity

\begin{tabular}{llll}
\hline $\begin{array}{l}\text { Floral } \\
\text { resource } \\
\text { availability }\end{array}$ & $\begin{array}{l}\text { On average XX flowering } \\
\text { plant species per } 100 \mathrm{~m}^{2} \text { in } \\
\text { road side verges in the period } \\
\text { May-August }\end{array}$ & $\begin{array}{l}\text { Municipalities, } \\
\text { Conservation } \\
\text { organizations }\end{array}$ & $\begin{array}{l}\text { Albrecht et al. } \\
\text { (2007) and Scheper } \\
\text { et al. (2013) }\end{array}$ \\
\hline No net loss & $\begin{array}{l}\text { Maintain biodiversity in an } \\
\text { equivalent or better state } \\
\text { than that observed at start of }\end{array}$ & $\begin{array}{l}\text { Infrastructure, } \\
\text { businesses }\end{array}$ & Pitz et al. (2016) \\
& project & & \\
\hline $\begin{array}{l}\text { Semi-natural } \\
\text { habitat cover }\end{array}$ & $\begin{array}{l}\text { A minimum of XX\% of land Farmers } \\
\text { area consists of semi-natural } \\
\text { habitats }\end{array}$ & $\begin{array}{l}\text { Cormont et al. } \\
\text { (2016) }\end{array}$ \\
\hline
\end{tabular}

Suitable ecological conditions

\begin{tabular}{|c|c|c|c|}
\hline $\begin{array}{l}\text { Nitrogen } \\
\text { surplus }\end{array}$ & $\begin{array}{l}\text { Surplus should be lower than } \\
\text { XX kg N/ha }\end{array}$ & Farmers & $\begin{array}{l}\text { Fraters et al. (2015) } \\
\text { and Schroder et al. } \\
(2007)\end{array}$ \\
\hline $\begin{array}{l}\mathrm{NH}_{3} \\
\text { emissions }\end{array}$ & $\begin{array}{l}\text { Maximum XX kg } \mathrm{NH}_{3} \\
\text { emitted per ha }\end{array}$ & Farmers & $\begin{array}{l}\text { Van Laarhoven } \\
\text { et al. (2018) }\end{array}$ \\
\hline $\begin{array}{l}\text { Groundwater } \\
\text { level }\end{array}$ & $\begin{array}{l}\text { XX percent of land with } \\
\text { water level not lower than } \\
20 \mathrm{~cm} \text { below field level }\end{array}$ & $\begin{array}{l}\text { Nature } \\
\text { conservation } \\
\text { organizations, } \\
\text { Farmers }\end{array}$ & $\begin{array}{l}\text { Verhoeven et al. } \\
(2017) \text { and } \\
\text { Wamelink et al. } \\
(2013)\end{array}$ \\
\hline \multicolumn{4}{|l|}{ Climate change } \\
\hline $\begin{array}{l}\text { Greenhouse } \\
\text { gas emissions }\end{array}$ & $\begin{array}{l}\text { Maximum XX ton } \\
\mathrm{CO}_{2} \text {-equivalent/ha }\end{array}$ & Farmers & Eckard et al. (2010) \\
\hline
\end{tabular}

Ideally KPIs can be easily measured or are already part of standard data collection such as statistics on farm nutrient balances that are routinely collected in some countries. XX denotes an agreed level of the indicator that is considered to be sufficient to reverse biodiversity loss, either stand-alone or in combination with other KPIs.

management prescriptions are often sustainability guidelines that benchmark farmers with themselves or with their peers (e.g. $90 \%$ less pesticides or $50 \%$ less fertilizer) without assessing whether the improvement in management will add up sufficiently on a landscape or ecosystem scale. Even if every 
single farmer improves performance this does not guarantee that this improvement is enough for restoring biodiversity and ecosystem functions at a landscape scale. KPIs can be used to benchmark farmers against what is needed from an ecosystem perspective. KPIs were originally developed in business as a quantifiable measure for evaluating the success of an organization in meeting its performance objectives. Using KPIs rather than prescribing management or directly linking conservation efforts to results by means of biodiversity indicators, such as the number of species or population size of plants and animals, has three important advantages. First, stakeholders have more freedom to choose how they are going to achieve the KPIs they committed to, thus allowing farmers to develop or demonstrate their skills. The restrictive nature of prescribing management practices in specific designated areas has been put forward as an important reason why farmers involved in agri-environment schemes do not become more motivated for nature conservation (Burton et al., 2008). Second, when chosen strategically, KPIs can be monitored much more efficiently and cheaply than most biodiversity indicators. For example, because they are part of national monitoring programmes, have to be reported by stakeholders within the framework of environmental policies or because they can be easily collected using remote sensing data. Third, wildlife can be affected by processes that are beyond the control of individual farmers and biodiversity benefits may fail to manifest even though a farmer implements the management correctly. In approaches that potentially link payments to biodiversity indicators, such as the number of plant species or the density of breeding pairs of target bird species, it would be unfair to hold farmers accountable for factors they cannot control. Furthermore, it is often more time-consuming to survey biodiversity indicators than it is to survey KPIs, which makes it more feasible to quantify KPIs at large spatial scales. KPI selection should ideally be based on scientific evidence that they are related to biodiversity and that the formulated thresholds likely result in positive biodiversity trends. It is furthermore important that KPIs do not inadvertently lead to local conservation benefits at the expense of biodiversity elsewhere on the planet. For example, conservation measures on dairy farms may reduce on-farm feed production which could lead to more demand for feed produced elsewhere, to the cost of biodiversity. This can be avoided by using integrated sets of KPIs that address local biodiversity benefits, wider environmental conditions and climate change (Table 1).

KPIs can be used in biodiversity-based business models and payment for ecosystem services schemes (Bullock et al., 2011; Fig. 2). The Swiss network 
bonus scheme (Kramer and Watzold, 2018) is essentially a working example. Farmers receive a bonus if they establish spatially connected conservation areas. The underlying ecological principle is that habitat fragmentation is a key driver of biodiversity decline (Krauss et al., 2010) and that using a certain level of connectivity as a requirement for extra financial rewards can be expected to enhance the effectiveness of conservation efforts. In the Netherlands, KPIs are currently being used in pilot projects to reward dairy farmers for efforts to create the conditions required for increasing biodiversity trends (Van Laarhoven et al., 2018). Rabobank, the leading financial services provider for the Dutch agricultural sector gives a discount on the interest rate of loans to farmers who score high on an integrated set of KPIs and Friesland Campina, the largest dairy company in the Netherlands rewards these farmers with a higher milk price. These companies are investing in this initiative because they think sustainable and biodiversity positive business models are expected to lead to longer-term viability of business models, increased market share, new business models and better relationships with stakeholders (The Sustainable Finance Platform, 2020). Furthermore, it may reduce risks with respect to investments, markets, legal liability, regulations and reputation. For example, expected stricter biodiversity-related regulations may result in regulatory risks for large companies and negative media attention for practices harming biodiversity may result in the reputational risk of clients backing out (Evison and Knight, 2010). Such economic incentives for biodiversity conservation can be important in facilitating transformations towards biodiversity-friendly farming (Iverson et al., 2019). However, care should be taken that the KPIs themselves do not become the ultimate objectives of management. For example, when land managers have to meet a minimum score in a tool that uses an integrated set of KPIs (Table 1) to qualify for financial incentives, they may select the set that requires the least changes in farm management rather than the set that makes the largest contribution to biodiversity conservation (Bullock et al., 2011). An additional risk of using economic incentives is that it can have adverse impacts on intrinsic motivation (Rode et al., 2015). It is important to realize that incentives can be more than financial benefits and include, for example a positive image by society and their peers (Greiner et al., 2009). Most of the aforementioned risks of using KPIs can be mitigated by evaluating whether realization of KPIs does indeed result in positive biodiversity trends. Monitoring and evaluating the relationships between management, KPIs and biodiversity is therefore essential. 


\subsection{Monitoring impact on biodiversity}

Adaptive management requires an understanding of conservation outcomes so that efforts can be improved when evidence suggests that practices are insufficient for achieving significant biodiversity effects. Although adaptive management is widely advocated as an effective conservation approach, surprisingly few studies have examined the ecological impacts of adaptive management (Gillson et al., 2019). Similarly, evidence of ecological effects of collaborative conservation approaches is virtually non-existent (Koontz et al., 2020). Studies evaluating conservation initiatives typically focus on a single practice and study effects in isolation (e.g. Jakobsson et al., 2018; Kleijn et al., 2006; Nicholson et al., 2020). A generally accepted method for an in situ evaluation of the effectiveness of conservation management is to select (pairs of) sites that are similar in soil type, landscape structure, groundwater level and other environmental variables that are known to influence biodiversity and only differ with respect to conservation management being implemented or not (Kleijn et al., 2006, 2014; Fig. 3A). Using a
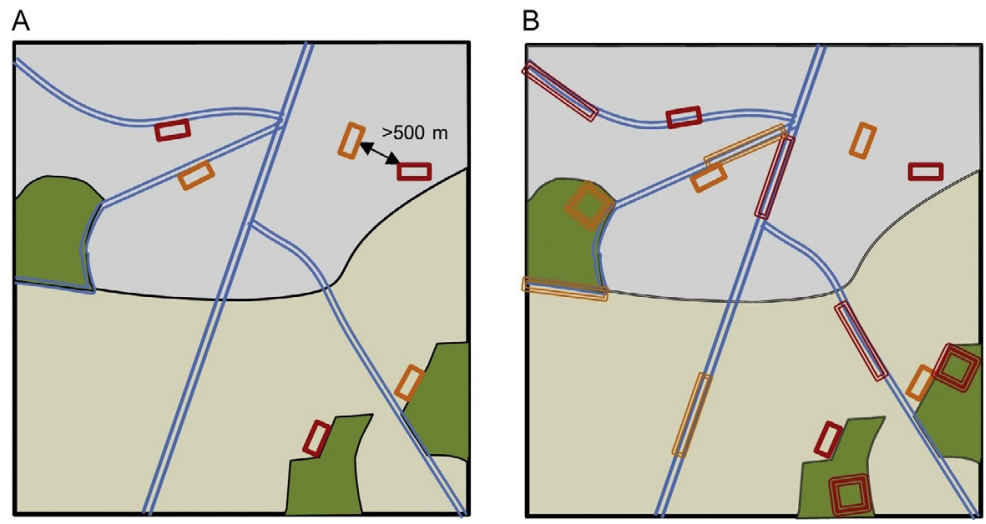

Fig. 3 An illustration of the differences between (A) landscape-scale study designs of conventional studies evaluating the effectiveness of conservation management of individual practices and (B) study designs of landscape-level collaborative multi-stakeholder approaches. Different shapes indicate different practices with red being conventionally managed sites and orange representing sites with conservation management. Because in landscape-level approaches the study area is fixed and the location of conservation management is largely determined by practical constraints of the participating stakeholders, the distribution of practices over sites with different environmental conditions may be skewed. Furthermore, conservation management will be implemented in close proximity of other sites with (other) conservation management. More advanced statistical methods therefore need to be developed to disentangle effects of individual conservation practices as well as the cumulative and interacting effects including reliable estimates of uncertainty. 
space-for-time design, differences in biodiversity levels measured in one or a few years can then be assigned to the effects of conservation management (e.g. Morandin and Kremen, 2013; Scheper et al., 2015; Tschumi et al., 2015). In contrast to experimental studies that have been established by scientists, this approach takes into account that conservation management by land-owners also reflects issues of cost-effectiveness or how well they fit into day-to-day management (Kleijn et al., 2004). However, this approach cannot be used to evaluate the effectiveness of landscape-level conservation approaches because the latter approach specifically aims to stack different conservation practices in close proximity to capitalize on potential synergies of implementing multiple practices together. Sites with one type of management may therefore be influenced by conservation management on other sites and it will be hard to find control sites that will not be influenced by nearby conservation management (Fig. 3B). Essentially, the entire landscape-level conservation initiative is a single experimental unit and should be replicated and compared to control landscapes without conservation initiatives to evaluate effectiveness. In practice this is rarely possible because of the large spatial scale of landscape-level approaches and because the multi-stakeholder approach requires a lot of time and effort.

Fig. 4 graphically displays a study design that can be used to evaluate landscape-level collaborative multi-stakeholder conservation initiatives. Rather than comparing sites with and without conservation management at one point in time it relies on longer-term monitoring to compare trends on sites with and without conservation management. The approach specifically integrates the area on which conservation management is being implemented and biodiversity trends on different types of control sites to be able to (i) distinguish trends caused by conservation management from trends caused by unrelated factors such as climate, (ii) link management to KPIs (Fig. 2) and (iii) be able to scale up effects of local management to landscape-level trends in biodiversity (Kleijn et al., 2018). Determining trends will also make it possible to determine whether the effects of conservation management are sufficient to achieve stable or positive biodiversity trends, which is generally not possible with studies that use space-for-time designs. Because the rate of population change is the main response variable of interest instead of relative biodiversity levels, having exactly the same environmental conditions in sites with and without conservation management will be less important. However, because controls inside the area with landscape-level conservation may be subject to spill-over from conservation sites, it will be important to include an extra control in the study design: sites 


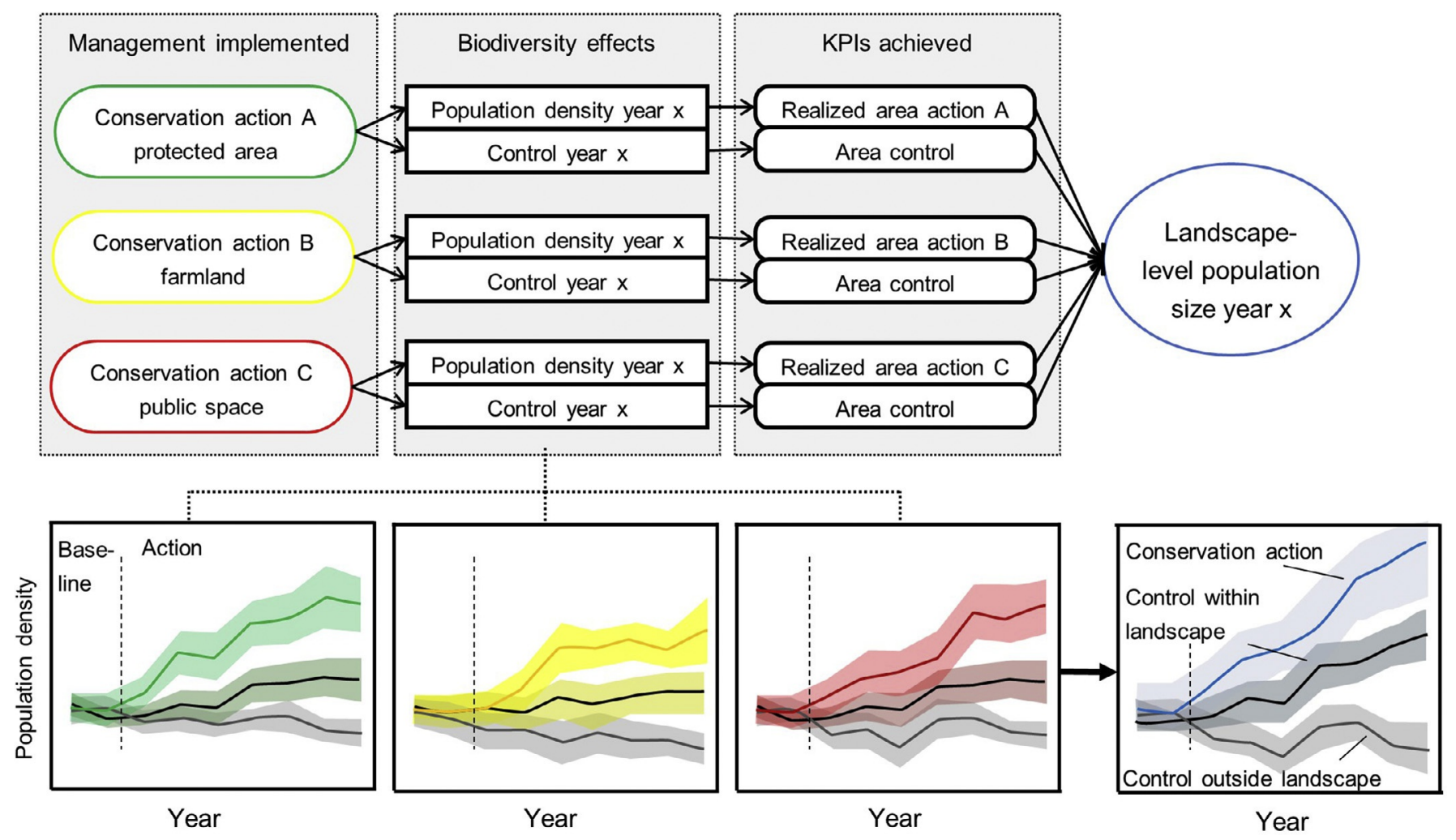

Fig. 4 A graphical outline of an approach that can be used to monitor effects of multiple conservation practices/actions implemented by different stakeholders in landscapes and how to scale up effects to landscape-level population sizes. Key Performance Indicators (KPIs) give the area in a landscape in which a certain quality of habitat has been achieved by conservation management. Multiplying KPI area by density estimates that have been obtained in a representative sample of conservation and control sites inside study landscapes can then be used to estimate landscape-level population sizes (Kleijn et al., 2018). Control sites outside the area with landscape-level conservation initiatives are needed to compare trends in the study area with autonomous biodiversity trends. 
without conservation management that are located outside the study landscape (Fig. 4). This approach relies on the assumption that the effects of management do not differ between sites with slightly different environmental conditions which may hold at regional but not necessarily at larger scales (Whittingham et al., 2007). The control areas outside the study landscape should therefore be beyond home range distance but otherwise as close as possible to the study landscape and experience similar environmental conditions. In principle, estimating the effects of individual management practices on biodiversity trends can then be done by examining whether the year $\times$ management interaction is influenced by the proportion of habitat with a certain type of management within a certain radius of each sampled site using statistical methods such as generalized linear mixed effects models. The sample sizes required to determine reliable and ecologically meaningful effects, the relevant spatial scales to address for different species groups and the methods to deal with the inevitable unplanned changes in management that are part of working in large-scale multi-stakeholder initiatives need to be worked out in more detail once the first data sets become available.

The ultimate objective of conservation is arguably to enhance biodiversity at spatial scales that are relevant to species populations. Yet we still know very little about the relationship between local conservation management and larger-scale biodiversity trends and responses (Kleijn et al., 2011). For most species groups it is too time-consuming to measure biodiversity throughout the landscape, even in landscape-level conservation approaches. To estimate larger-scale biodiversity effects, study designs should therefore allow for the scaling up of locally measured effects. This can be done by multiplying the measured population densities in habitats with and without conservation management by the area these habitats occupy in the landscape (Kleijn et al., 2018; Fig. 4). Note that, while all monitoring techniques are subject to bias, scaling up local effects requires area-based monitoring methods (e.g. permanent quadrats, transect surveys, territory mapping) that are employed randomly or representatively over different habitats. Methods that measure activity density (e.g. pitfall traps, pan traps, camera traps, point counts) cannot be scaled up because the observed number of individuals cannot be linked to a specific area or habitat.

\section{Conclusions}

In this paper we have outlined an approach that combines and integrates key elements from different conservation strategies. The approach 
essentially represents the inclusion of evidence-based components in a landscape-level multi-stakeholder adaptive management initiative. A pivotal aspect is that the outcomes of evaluation studies are continuously being used to iteratively improve the evidence base and subsequently conservation management (Gillson et al., 2019). It's a strength that this allows for the findings of research in practical, real-world systems to be used directly by land managers to justify their efforts and further improve their activities. The approach basically attempts to steer a social-economic-ecological network into a more biodiverse direction, which is a complex endeavour and depends on a range of internal and external conditions. Effective implementation will be knowledge intensive and will require long-term commitment from a wide range of stakeholders as biodiversity responses may take time to become visible. Our approach shares this potential weakness with all other approaches that might work. Traditional conservation instruments and strategies have been insufficient to halt the ongoing biodiversity decline. It is time to test run more ambitious approaches.

\section{Acknowledgements}

Many of the insights presented in this manuscript have been developed during the many discussions with the Core Group of the Dutch Delta Plan Biodiversity Recovery and during the process of writing the proposal for the EU funded H2020 SHOWCASE project (project 862480 ). Thanks to all involved for the inspirational interactions.

\section{References}

Abrams, R.W., Anwana, E.D., Ormsby, A., Dovie, D.B.K., Ajagbe, A., Abrams, A., 2009. Integrating top-down with bottom-up conservation policy in Africa. Conserv. Biol. 23 (4), 799-804.

Albrecht, M., Duelli, P., Muller, C., Kleijn, D., Schmid, B., 2007. The Swiss agrienvironment scheme enhances pollinator diversity and plant reproductive success in nearby intensively managed farmland. J. Appl. Ecol. 44 (4), 813-822.

Anonymous, 2018. Delta Plan for Biodiversity Recovery-Taking Action for a Richer Netherlands. URL https://www.samenvoorbiodiversiteit.nl/wp-content/uploads/ 2019/04/Delta-Plan-for-Biodiversity-Recovery.pdf. Last accessed: 14-10-2020.

Baker, D.J., Freeman, S.N., Grice, P.V., Siriwardena, G.M., 2012. Landscape-scale responses of birds to agri-environment management: a test of the English Environmental Stewardship scheme. J. Appl. Ecol. 49 (4), 871-882.

Batary, P., Baldi, A., Kleijn, D., Tscharntke, T., 2011. Landscape-moderated biodiversity effects of agri-environmental management: a meta-analysis. Proc. R. Soc. B Biol. Sci. 278 (1713), 1894-1902.

Batary, P., Dicks, L.V., Kleijn, D., Sutherland, W.J., 2015. The role of agri-environment schemes in conservation and environmental management. Conserv. Biol. 29 (4), 1006-1016. 
Binzenhofer, B., Biedermann, R., Settele, J., Schroder, B., 2008. Connectivity compensates for low habitat quality and small patch size in the butterfly Cupido minimus. Ecol. Res. 23 (2), 259-269.

Bott, S., Cantrill, J.G., Myers, O.E., 2003. Place and the promise of conservation psychology. Hum. Ecol. Rev. 10, 100-112.

Bratman, G.N., Hamilton, J.P., Hahn, K.S., Daily, G.C., Gross, J.J., 2015. Nature experience reduces rumination and subgenual prefrontal cortex activation. Proc. Natl. Acad. Sci. U. S. A. 112 (28), 8567-8572.

Brown, J., et al., in press. How bioregional history shapes the past and future of agriculture: softening the blow by managing ecological similarities between agriculture and the ecosystems it replaces. In: Bohan, D.A., Vanbergen, A.J. (Eds.), Advances in Ecological Research, 64. Elsevier.

Bruner, A.G., Gullison, R.E., Balmford, A., 2004. Financial costs and shortfalls of managing and expanding protected-area systems in developing countries. Bioscience 54 (12), $1119-1126$.

Buijs, A., Mattijssen, T., Arts, B., 2014. "The man, the administration and the counterdiscourse": an analysis of the sudden turn in Dutch nature conservation policy. Land Use Policy 38, 676-684.

Bullock, J.M., Aronson, J., Newton, A.C., Pywell, R.F., Rey-Benayas, J.M., 2011. Restoration of ecosystem services and biodiversity: conflicts and opportunities. Trends Ecol. Evol. 26 (10), 541-549.

Burton, R.J.F., Kuczera, C., Schwarz, G., 2008. Exploring farmers' cultural resistance to voluntary agri-environmental schemes. Sociol. Rural. 48 (1), 16-37.

Butchart, S.H.M., Walpole, M., Collen, B., van Strien, A., Scharlemann, J.P.W., Almond, R.E.A., Baillie, J.E.M., Bomhard, B., Brown, C., Bruno, J., Carpenter, K.E., Carr, G.M., Chanson, J., Chenery, A.M., Csirke, J., Davidson, N.C., Dentener, F., Foster, M., Galli, A., Galloway, J.N., Genovesi, P., Gregory, R.D., Hockings, M., Kapos, V., Lamarque, J.F., Leverington, F., Loh, J., McGeoch, M.A., McRae, L., Minasyan, A., Morcillo, M.H., Oldfield, T.E.E., Pauly, D., Quader, S., Revenga, C., Sauer, J.R., Skolnik, B., Spear, D., StanwellSmith, D., Stuart, S.N., Symes, A., Tierney, M., Tyrrell, T.D., Vie, J.C., Watson, R., 2010. Global biodiversity: indicators of recent declines. Science 328 (5982), 1164-1168.

Butchart, S.H.M., Scharlemann, J.P.W., Evans, M.I., Quader, S., Arico, S., Arinaitwe, J., Balman, M., Bennun, L.A., Bertzky, B., Besancon, C., Boucher, T.M., Brooks, T.M., Burfield, I.J., Burgess, N.D., Chan, S., Clay, R.P., Crosby, M.J., Davidson, N.C., De Silva, N., Devenish, C., Dutson, G.C.L., Fernandez, D., Fishpool, L.D.C., Fitzgerald, C., Foster, M., Heath, M.F., Hockings, M., Hoffmann, M., Knox, D., Larsen, F.W., Lamoreux, J.F., Loucks, C., May, I., Millett, J., Molloy, D., Morling, P., Parr, M., Ricketts, T.H., Seddon, N., Skolnik, B., Stuart, S.N., Upgren, A., Woodley, S., 2012. Protecting important sites for biodiversity contributes to meeting global conservation targets. PLoS One 7 (3), 8.

Confer, J.L., Pascoe, S.M., 2003. Avian communities on utility rights-of-ways and other managed shrublands in the northeastern United States. For. Ecol. Manage. 185 (1-2), 193-205.

Cook, C.N., Possingham, H.P., Fuller, R.A., 2013. Contribution of systematic reviews to management decisions. Conserv. Biol. 27 (5), 902-915.

Cormont, A., Siepel, H., Clement, J., Melman, T.C.P., WallisDeVries, M.F., van Turnhout, C.A.M., Sparrius, L.B., Reemer, M., Biesmeijer, J.C., Berendse, F., de Snoo, G.R., 2016. Landscape complexity and farmland biodiversity: evaluating the CAP target on natural elements. J. Nat. Conserv. 30, 19-26. 
Daams, M.N., Sijtsma, F.J., van der Vlist, A.J., 2016. The effect of natural space on nearby property prices: accounting for perceived attractiveness. Land Econ. 92 (3), 389-410.

Dahler, N.B., Holderegger, R., Bergamini, A., Info, F., 2019. Effectiveness of Swiss protected areas in maintaining populations of rare vascular plants. J. Nat. Conserv. 52, 6.

Daily, G.C., Polasky, S., Goldstein, J., Kareiva, P.M., Mooney, H.A., Pejchar, L., Ricketts, T.H., Salzman, J., Shallenberger, R., 2009. Ecosystem services in decision making: time to deliver. Front. Ecol. Environ. 7 (1), 21-28.

D’Amico, M., Periquet, S., Roman, J., Revilla, E., 2016. Road avoidance responses determine the impact of heterogeneous road networks at a regional scale. J. Appl. Ecol. 53 (1), 181-190.

Davidson, C., Knapp, R.A., 2007. Multiple stressors and amphibian declines: dual impacts of pesticides and fish on yellow-legged frogs. Ecol. Appl. 17 (2), 587-597.

Day, J., Dudley, N., Hockings, M., Holmes, G., Laffoley, D., Stolton, S., Wells, S., Wenzel, L., 2019. Guidelines for Applying the IUCN Protected Area Management Categories to Marine Protected Areas, second ed. IUCN, Gland. Switzerland.

de Vries, S., Buijs, A.E., Langers, F., Farjon, H., van Hinsberg, A., Sijtsma, F.J., 2013. Measuring the attractiveness of Dutch landscapes: identifying national hotspots of highly valued places using Google Maps. Appl. Geogr. 45, 220-229.

DeFries, R., Rovero, F., Wright, P., Ahumada, J., Andelman, S., Brandon, K., Dempewolf, J., Hansen, A., Hewson, J., Liu, J.G., 2010. From plot to landscape scale: linking tropical biodiversity measurements across spatial scales. Front. Ecol. Environ. 8 (3), 153-160.

Deguines, N., Jono, C., Baude, M., Henry, M., Julliard, R., Fontaine, C., 2014. Large-scale trade-off between agricultural intensification and crop pollination services. Front. Ecol. Environ. 12 (4), 212-217.

Donald, P.F., Evans, A.D., 2006. Habitat connectivity and matrix restoration: the wider implications of agri-environment schemes. J. Appl. Ecol. 43 (2), 209-218.

Donald, P.F., Sanderson, F.J., Burfield, I.J., Bierman, S.M., Gregory, R.D., Waliczky, Z., 2007. International conservation policy delivers benefits for birds in Europe. Science 317 (5839), 810-813.

Driscoll, D.A., Banks, S.C., Barton, P.S., Lindenmayer, D.B., Smith, A.L., 2013. Conceptual domain of the matrix in fragmented landscapes. Trends Ecol. Evol. 28 (10), 605-613.

Duffy, M., 2009. Economies of size in production agriculture. J. Hunger Environ. Nutr. 4, 375-392.

Eckard, R.J., Grainger, C., de Klein, C.A.M., 2010. Options for the abatement of methane and nitrous oxide from ruminant production: a review. Livest. Sci. 130 (1-3), 47-56.

EEA, 2012. Protected Areas in Europe-An Overview. EEA Report No 5/2012. European Environment Agency, Copenhagen, Denmark.

EEA, 2019. Land Take in Europe. European Environment Agency, Copenhagen, Denmark.

Evison, W., Knight, C., 2010. Biodiversity and Business Risk-A Global Risks Network Briefing. World Economic Forum. URL https://www.pwc.co.uk/assets/pdf/wefbiodiversity-and-business-risk.pdf. Last accessed: 17 June 2020.

Fijen, T.P.M., Scheper, J.A., Vogel, C., van Ruijven, J., Kleijn, D., 2020. Insect pollination is the weakest link in the production of a hybrid seed crop. Agric. Ecosyst. Environ. 290, 106743.

Foxcroft, L.C., Jarosik, V., Pysek, P., Richardson, D.M., Rouget, M., 2011. Protected-area boundaries as filters of plant invasions. Conserv. Biol. 25 (2), 400-405.

Fraters, D., van Leeuwen, T., Boumans, L., Reijs, J., 2015. Use of long-term monitoring data to derive a relationship between nitrogen surplus and nitrate leaching for grassland and arable land on well-drained sandy soils in the Netherlands. Acta Agric. Scand. Sect. B Soil Plant Sci. 65, 144-154. 
Garcia-Amado, L.R., Perez, M.R., Garcia, S.B., 2013. Motivation for conservation: assessing integrated conservation and development projects and payments for environmental services in La Sepultura Biosphere Reserve, Chiapas, Mexico. Ecol. Econ. 89, 92-100.

Gardiner, M.M., Riley, C.B., Bommarco, R., Ockinger, E., 2018. Rights-of-way: a potential conservation resource. Front. Ecol. Environ. 16 (3), 149-158.

Garibaldi, L.A., Steffan-Dewenter, I., Winfree, R., Aizen, M.A., Bommarco, R., Cunningham, S.A., Kremen, C., Carvalheiro, L.G., Harder, L.D., Afik, O., Bartomeus, I., Benjamin, F., Boreux, V., Cariveau, D., Chacoff, N.P., Dudenhoffer, J.H., Freitas, B.M., Ghazoul, J., Greenleaf, S., Hipolito, J., Holzschuh, A., Howlett, B., Isaacs, R., Javorek, S.K., Kennedy, C.M., Krewenka, K.M., Krishnan, S., Mandelik, Y., Mayfield, M.M., Motzke, I., Munyuli, T., Nault, B.A., Otieno, M., Petersen, J., Pisanty, G., Potts, S.G., Rader, R., Ricketts, T.H., Rundlof, M., Seymour, C.L., Schuepp, C., Szentgyorgyi, H., Taki, H., Tscharntke, T., Vergara, C.H., Viana, B.F., Wanger, T.C., Westphal, C., Williams, N., Klein, A.M., 2013. Wild pollinators enhance fruit set of crops regardless of honey bee abundance. Science 339 (6127), 1608-1611.

Gaston, K.J., Jackson, S.E., Nagy, A., Cantu-Salazar, L., Johnson, M., 2008. Protected areas in Europe-principle and practice. In: Ostfeld, R.S., Schlesinger, W.H. (Eds.), Year in Ecology and Conservation Biology. New York Academy of Sciences, pp. 97-119.

Gillson, L., Biggs, H., Smit, I.P.J., Virah-Sawmy, M., Rogers, K., 2019. Finding common ground between adaptive management and evidence-based approaches to biodiversity conservation. Trends Ecol. Evol. 34 (1), 31-44.

Gonthier, D.J., Ennis, K.K., Farinas, S., Hsieh, H.Y., Iverson, A.L., Batary, P., Rudolphi, J., Tscharntke, T., Cardinale, B.J., Perfecto, I., 2014. Biodiversity conservation in agriculture requires a multi-scale approach. Proc. R. Soc. B Biol. Sci. 281 (1791), 8.

Grass, I., Batáry, P., Tscharntke, T., in press. Combining land-sparing and land-sharing in European landscapes. Adv. Ecol. Res. 64.

Gregory, R.D., Vorisek, P., Noble, D.G., Van Strien, A., Klvanova, A., Eaton, M., Meyling, A.W.G., Joys, A., Foppen, R.P.B., Burfield, I.J., 2008. The generation and use of bird population indicators in Europe. Bird Conserv. Int. 18, S223-S244.

Greiner, R., Patterson, L., Miller, O., 2009. Motivations, risk perceptions and adoption of conservation practices by farmers. Agr. Syst. 99 (2-3), 86-104.

Gustafsson, K.M., Agrawal, A.A., Lewenstein, B.V., Wolf, S.A., 2015. The monarch butterfly through time and space: the social construction of an icon. Bioscience 65 (6), $612-622$.

Gutierrez, N.L., Hilborn, R., Defeo, O., 2011. Leadership, social capital and incentives promote successful fisheries. Nature 470 (7334), 386-389.

Hagen, M., Kissling, W.D., Rasmussen, C., De Aguiar, M.A.M., Brown, L.E., Carstensen, D.W., Alves-Dos-Santos, I., Dupont, Y.L., Edwards, F.K., Genini, J., Guimaraes, P.R., Jenkins, G.B., Jordano, P., Kaiser-Bunbury, C.N., Ledger, M.E., Maia, K.P., Marquitti, F.M.D., McLaughlin, O., Morellato, L.P.C., O’Gorman, E.J., Trojelsgaard, K., Tylianakis, J.M., Vidal, M.M., Woodward, G., Olesen, J.M., 2012. Biodiversity, species interactions and ecological networks in a fragmented world. In: Jacob, U., Woodward, G. (Eds.), Advances in Ecological Research, Vol 46: Global Change in Multispecies Systems, Pt 1. Elsevier Academic Press Inc., San Diego, pp. 89-210.

Hallmann, C.A., Sorg, M., Jongejans, E., Siepel, H., Hofland, N., Schwan, H., Stenmans, W., Muller, A., Sumser, H., Horren, T., Goulson, D., de Kroon, H., 2017. More than 75 percent decline over 27 years in total flying insect biomass in protected areas. PLoS One 12 (10), 1-21. 
Heath, S.K., Long, R.F., 2019. Multiscale habitat mediates pest reduction by birds in an intensive agricultural region. Ecosphere 10 (10), 24.

Heneberg, P., Bogusch, P., Rezac, M., 2017. Roadside verges can support spontaneous establishment of steppe-like habitats hosting diverse assemblages of bees and wasps (Hymenoptera: Aculeata) in an intensively cultivated central European landscape. Biodivers. Conserv. 26 (4), 843-864.

Holm, T.E., Laursen, K., 2009. Experimental disturbance by walkers affects behaviour and territory density of nesting Black-tailed Godwit Limosa limosa. Ibis 151 (1), 77-87.

IPBES, 2019. In: Díaz, S., Settele, J., Brondízio, E.S., Ngo, H.T., Guèze, M., Agard, J., Zayas, C.N. (Eds.), Summary for Policymakers of the Global Assessment Report on Biodiversity and Ecosystem Services of the Intergovernmental Science-Policy Platform on Biodiversity and Ecosystem Services. IPBES secretariat, Bonn, Germany. 56 pages.

Iverson, A.L., Gonthier, D.J., Pak, D., Ennis, K.K., Burnham, R.J., Perfecto, I., Rodriguez, M.R., Vandermeer, J.H., 2019. A multifunctional approach for achieving simultaneous biodiversity conservation and farmer livelihood in coffee agroecosystems. Biol. Conserv. 238, 11.

Jakobsson, S., Bernes, C., Bullock, J.M., Verheyen, K., Lindborg, R., 2018. How does roadside vegetation management affect the diversity of vascular plants and invertebrates? A systematic review. Environ. Evid. 7 (1), 14.

Kennedy, C.M., Lonsdorf, E., Neel, M.C., Williams, N.M., Ricketts, T.H., Winfree, R., Bommarco, R., Brittain, C., Burley, A.L., Cariveau, D., Carvalheiro, L.G., Chacoff, N.P., Cunningham, S.A., Danforth, B.N., Dudenhoffer, J.H., Elle, E., Gaines, H.R., Garibaldi, L.A., Gratton, C., Holzschuh, A., Isaacs, R., Javorek, S.K., Jha, S., Klein, A.M., Krewenka, K., Mandelik, Y., Mayfield, M.M., Morandin, L., Neame, L.A., Otieno, M., Park, M., Potts, S.G., Rundlof, M., Saez, A., SteffanDewenter, I., Taki, H., Viana, B.F., Westphal, C., Wilson, J.K., Greenleaf, S.S., Kremen, C., 2013. A global quantitative synthesis of local and landscape effects on wild bee pollinators in agroecosystems. Ecol. Lett. 16 (5), 584-599.

Kennedy, C.M., Oakleaf, J.R., Theobald, D.M., Baruch-Mordo, S., Kiesecker, J., 2019. Managing the middle: a shift in conservation priorities based on the global human modification gradient. Glob. Chang. Biol. 25 (3), 811-826.

Kleijn, D., Berendse, F., Smit, R., Gilissen, N., Smit, J., Brak, B., Groeneveld, R., 2004. Ecological effectiveness of agri-environment schemes in different agricultural landscapes in the Netherlands. Conserv. Biol. 18 (3), 775-786.

Kleijn, D., Baquero, R.A., Clough, Y., Diaz, M., De Esteban, J., Fernandez, F., Gabriel, D., Herzog, F., Holzschuh, A., Johl, R., Knop, E., Kruess, A., Marshall, E.J.P., SteffanDewenter, I., Tscharntke, T., Verhulst, J., West, T.M., Yela, J.L., 2006. Mixed biodiversity benefits of agri-environment schemes in five European countries. Ecol. Lett. 9 (3), 243-254.

Kleijn, D., Bekker, R.M., Bobbink, R., De Graaf, M.C.C., Roelofs, J.G.M., 2008. In search for key biogeochemical factors affecting plant species persistence in heathland and acidic grasslands: a comparison of common and rare species. J. Appl. Ecol. 45 (2), 680-687.

Kleijn, D., Rundlof, M., Scheper, J., Smith, H.G., Tscharntke, T., 2011. Does conservation on farmland contribute to halting the biodiversity decline? Trends Ecol. Evol. 26 (9), 474-481.

Kleijn, D., Cherkaoui, I., Goedhart, P.W., van der Hout, J., Lammertsma, D., 2014. Waterbirds increase more rapidly in Ramsar-designated wetlands than in unprotected wetlands. J. Appl. Ecol. 51 (2), 289-298.

Kleijn, D., Linders, T.E.W., Stip, A., Biesmeijer, J.C., Wackers, F.L., Bukovinszky, T., 2018. Scaling up effects of measures mitigating pollinator loss from local- to landscape-level population responses. Methods Ecol. Evol. 9 (7), 1727-1738. 
Kleijn, D., Bommarco, R., Fijen, T.P.M., Garibaldi, L.A., Potts, S.G., van der Putten, W.H., 2019. Ecological intensification: bridging the gap between science and practice. Trends Ecol. Evol. 34 (2), 154-166.

Knight, M.E., Martin, A.P., Bishop, S., Osborne, J.L., Hale, R.J., Sanderson, A., Goulson, D., 2005. An interspecific comparison of foraging range and nest density of four bumblebee (Bombus) species. Mol. Ecol. 14 (6), 1811-1820.

Kohler, F., Verhulst, J., van Klink, R., Kleijn, D., 2008. At what spatial scale do high-quality habitats enhance the diversity of forbs and pollinators in intensively farmed landscapes? J. Appl. Ecol. 45 (3), 753-762.

Koontz, T.M., Jager, N.W., Newig, J., 2020. Assessing collaborative conservation: a case survey of output, outcome, and impact measures used in the empirical literature. Soc. Nat. Resour. 33 (4), 442-461.

Kramer, J.E., Watzold, F., 2018. The agglomeration bonus in practice-an exploratory assessment of the Swiss network bonus. J. Nat. Conserv. 43, 126-135.

Krauss, J., Bommarco, R., Guardiola, M., Heikkinen, R.K., Helm, A., Kuussaari, M., Lindborg, R., Ockinger, E., Partel, M., Pino, J., Poyry, J., Raatikainen, K.M., Sang, A., Stefanescu, C., Teder, T., Zobel, M., Steffan-Dewenter, I., 2010. Habitat fragmentation causes immediate and time-delayed biodiversity loss at different trophic levels. Ecol. Lett. 13 (5), 597-605.

Kremen, C., Merenlender, A.M., 2018. Landscapes that work for biodiversity and people. Science 362 (6412), 1-9.

Krimmer, E., Martin, E.A., Krauss, J., Holzschuh, A., Steffan-Dewenter, I., 2019. Size, age and surrounding semi-natural habitats modulate the effectiveness of flower-rich agrienvironment schemes to promote pollinator visitation in crop fields. Agric. Ecosyst. Environ. 284, 8.

Lambert, D.M., Sullivan, P., Claassen, R., Foreman, L., 2007. Profiles of US farm households adopting conservation-compatible practices. Land Use Policy 24 (1), 72-88.

Leng, X., Musters, C.J.M., de Snoo, G.R., 2009. Restoration of plant diversity on ditch banks: seed and site limitation in response to agri-environment schemes. Biol. Conserv. 142 (7), 1340-1349.

Liu, Y.B., Pan, X.B., Li, J.S., 2015. Current agricultural practices threaten future global food production. J. Agric. Environ. Ethics 28 (2), 203-216.

McCarthy, D.P., Donald, P.F., Scharlemann, J.P.W., Buchanan, G.M., Balmford, A., Green, J.M.H., Bennun, L.A., Burgess, N.D., Fishpool, L.D.C., Garnett, S.T., Leonard, D.L., Maloney, R.F., Morling, P., Schaefer, H.M., Symes, A., Wiedenfeld, D.A., Butchart, S.H.M., 2012. Financial costs of meeting global biodiversity conservation targets: current spending and unmet needs. Science 338 (6109), 946-949.

McKenzie, A.J., Emery, S.B., Franks, J.R., Whittingham, M.J., 2013. Landscape-scale conservation: collaborative agri-environment schemes could benefit both biodiversity and ecosystem services, but will farmers be willing to participate? J. Appl. Ecol. 50 (5), $1274-1280$.

Meijer, W., 1975. Nota betreffende de relatie landbouw en natuur- en landschapsbehoud: gemeenschappelijke uitgangspunten voor het beleid inzake de uit een oogpunt van natuur- en landschapsbehoud waardevolle agrarische cultuurlandschappen. Ministerie van Cultuur, Recreatie en Maatschappelijk werk, Ministerie van Landbouw en Visserij en Ministerie van Volkshuisvesting en Ruimtelijke Ordening, Den Haag.

Mendenhall, C.D., Shields-Estrada, A., Krishnaswami, A.J., Daily, G.C., 2016. Quantifying and sustaining biodiversity in tropical agricultural landscapes. Proc. Natl. Acad. Sci. U. S. A. 113 (51), 14544-14551.

Morandin, L.A., Kremen, C., 2013. Hedgerow restoration promotes pollinator populations and exports native bees to adjacent fields. Ecol. Appl. 23 (4), 829-839. 
Nicholson, C.C., Ward, K.L., Williams, N.M., Isaacs, R., Mason, K.S., Wilson, J.K., Brokaw, J., Gut, L.J., Rothwell, N.L., Wood, T.J., Rao, S., Hoffman, G.D., Gibbs, J., Thorp, R.W., Ricketts, T.H., 2020. Mismatched outcomes for biodiversity and ecosystem services: testing the responses of crop pollinators and wild bee biodiversity to habitat enhancement. Ecol. Lett. 23 (2), 326-335.

Nielsen, T.F., Sand-Jensen, K., Dornelas, M., Bruun, H.H., 2019. More is less: net gain in species richness, but biotic homogenization over 140 years. Ecol. Lett. 22 (10), 1650-1657.

Ortega, J., Zaidan, F., 2009. Observations of flotsam entrapment in the northern diamondbacked watersnake (Nerodia r. rhombifer). Herpetol. Conserv. Biol. 4 (2), 270-276.

Osborne, J.L., Clark, S.J., Morris, R.J., Williams, I.H., Riley, J.R., Smith, A.D., Reynolds, D.R., Edwards, A.S., 1999. A landscape-scale study of bumble bee foraging range and constancy, using harmonic radar. J. Appl. Ecol. 36 (4), 519-533.

Packer, C., Loveridge, A., Canney, S., Caro, T., Garnett, S.T., Pfeifer, M., Zander, K.K., Swanson, A., MacNulty, D., Balme, G., Bauer, H., Begg, C.M., Begg, K.S., Bhalla, S., Bissett, C., Bodasing, T., Brink, H., Burger, A., Burton, A.C., Clegg, B., Dell, S., Delsink, A., Dickerson, T., Dloniak, S.M., Druce, D., Frank, L., Funston, P., Gichohi, N., Groom, R., Hanekom, C., Heath, B., Hunter, L., DeIongh, H.H., Joubert, C.J., Kasiki, S.M., Kissui, B., Knocker, W., Leathem, B., Lindsey, P.A., Maclennan, S.D., McNutt, J.W., Miller, S.M., Naylor, S., Nel, P., Ng'weno, C., Nicholls, K., Ogutu, J.O., Okot-Omoya, E., Patterson, B.D., Plumptre, A., Salerno, J., Skinner, K., Slotow, R., Sogbohossou, E.A., Stratford, K.J., Winterbach, C., Winterbach, H., Polasky, S., 2013. Conserving large carnivores: dollars and fence. Ecol. Lett. 16 (5), 635-641.

Pe'er, G., Tsianou, M.A., Franz, K.W., Matsinos, Y.G., Mazaris, A.D., Storch, D., Kopsova, L., Verboom, J., Baguette, M., Stevens, V.M., Henle, K., 2014. Toward better application of minimum area requirements in conservation planning. Biol. Conserv. 170, 92-102.

Pe'er, G., Zinngrebe, Y., Hauck, J., Schindler, S., Dittrich, A., Zingg, S., Tscharntke, T., Oppermann, R., Sutcliffe, L.M.E., Sirami, C., Schmidt, J., Hoyer, C., Schleyer, C., Lakner, S., 2017. Adding some green to the greening: improving the EU's ecological focus areas for biodiversity and farmers. Conserv. Lett. 10 (5), 517-530.

Perino, A., Pereira, H.M., Navarro, L.M., Fernandez, N., Bullock, J.M., Ceausu, S., CortesAvizanda, A., van Klink, R., Kuemmerle, T., Lomba, A., Pe'er, G., Plieninger, T., Benayas, J.M.R., Sandom, C.J., Svenning, J.C., Wheeler, H.C., 2019. Rewilding complex ecosystems. Science 364 (6438), 351.

Pimm, S.L., Jenkins, C.N., Abell, R., Brooks, T.M., Gittleman, J.L., Joppa, L.N., Raven, P.H., Roberts, C.M., Sexton, J.O., 2014. The biodiversity of species and their rates of extinction, distribution, and protection. Science 344 (6187), 987.

Pitz, C., Mahy, G., Vermeulen, C., Marlet, C., Seleck, M., 2016. Developing biodiversity indicators on a stakeholders' opinions basis: the gypsum industry Key Performance Indicators framework. Environ. Sci. Pollut. Res. 23 (14), 13661-13671.

Plard, F., Bruns, H.A., Cimiotti, D.V., Helmecke, A., Hotker, H., Jeromin, H., Roodbergen, M., Schekkerman, H., Teunissen, W., van der Jeugd, H., Schaub, M., 2020. Low productivity and unsuitable management drive the decline of central European lapwing populations. Anim. Conserv. 23, 286-296.

Polasky, S., Nelson, E., Pennington, D., Johnson, K.A., 2011. The impact of land-use change on ecosystem services, biodiversity and returns to landowners: a case study in the State of Minnesota. Environ. Resource Econ. 48 (2), 219-242.

Poschlod, P., Bakker, J.P., Kahmen, S., 2005. Changing land use and its impact on biodiversity. Basic Appl. Ecol. 6 (2), 93-98. 
Purdue, D., 2001. Neighbourhood governance: leadership, trust and social capital. Urban Stud. 38 (12), 2211-2224.

Pywell, R.F., Bullock, J.M., Roy, D.B., Warman, L.I.Z., Walker, K.J., Rothery, P., 2003. Plant traits as predictors of performance in ecological restoration. J. Appl. Ecol. 40 (1), 65-77.

Qing, J., Yang, Z.S., He, K., Zhang, Z.J., Gu, X.D., Yang, X.Y., Zhang, W., Yang, B., Qi, D.W., Dai, Q., 2016. The minimum area requirements (MAR) for giant panda: an empirical study. Sci. Rep. 6, 37715.

Rands, M.R.W., Adams, W.M., Bennun, L., Butchart, S.H.M., Clements, A., Coomes, D., Entwistle, A., Hodge, I., Kapos, V., Scharlemann, J.P.W., Sutherland, W.J., Vira, B., 2010. Biodiversity conservation: challenges beyond 2010. Science 329 (5997), 1298-1303.

Rasmussen, J.J., Baattrup-Pedersen, A., Wiberg-Larsen, P., McKnight, U.S., Kronvang, B., 2011. Buffer strip width and agricultural pesticide contamination in Danish lowland streams: implications for stream and riparian management. Ecol. Eng. 37 (12), 1990-1997.

Redpath, S.M., Linnell, J.D.C., Festa-Bianchet, M., Boitani, L., Bunnefeld, N., Dickman, A., Gutierrez, R.J., Irvine, R.J., Johansson, M., Majic, A., McMahon, B.J., Pooley, S., Sandstrom, C., Sjolander-Lindqvist, A., Skogen, K., Swenson, J.E., Trouwborst, A., Young, J., Milner-Gulland, E.J., 2017. Don't forget to look down - collaborative approaches to predator conservation. Biol. Rev. 92 (4), 2157-2163.

Ricketts, T.H., 2001. The matrix matters: effective isolation in fragmented landscapes. Am. Nat. 158 (1), 87-99.

Ritchie, E.G., Johnson, C.N., 2009. Predator interactions, mesopredator release and biodiversity conservation. Ecol. Lett. 12 (9), 982-998.

Robledano, F., Esteve, M.A., Farinos, P., Carreno, M.F., Martinez-Fernandez, J., 2010. Terrestrial birds as indicators of agricultural-induced changes and associated loss in conservation value of Mediterranean wetlands. Ecol. Indic. 10 (2), 274-286.

Rode, J., Gomez-Baggethun, E., Krause, T., 2015. Motivation crowding by economic incentives in conservation policy: a review of the empirical evidence. Ecol. Econ. 117, 270-282.

Runhaar, H., Driessen, P., Uittenbroek, C., 2014. Towards a systematic framework for the analysis of environmental policy integration. Environ. Policy Gov. 24 (4), 233-246.

Sanderson, F.J., Pople, R.G., Ieronymidou, C., Burfield, I.J., Gregory, R.D., Willis, S.G., Howard, C., Stephens, P.A., Beresford, A.E., Donald, P.F., 2016. Assessing the performance of EU nature legislation in protecting target bird species in an era of climate change. Conserv. Lett. 9 (3), 172-180.

Sayer, J., Sunderland, T., Ghazoul, J., Pfund, J.L., Sheil, D., Meijaard, E., Venter, M., Boedhihartono, A.K., Day, M., Garcia, C., van Oosten, C., Buck, L.E., 2013. Ten principles for a landscape approach to reconciling agriculture, conservation, and other competing land uses. Proc. Natl. Acad. Sci. U. S. A. 110 (21), 8349-8356.

Sayer, J.A., Margules, C., Boedhihartono, A.K., Sunderland, T., Langston, J.D., Reed, J., Riggs, R., Buck, L.E., Campbell, B.M., Kusters, K., Elliott, C., Minang, P.A., Dale, A., Purnomo, H., Stevenson, J.R., Gunarso, P., Purnomo, A., 2017. Measuring the effectiveness of landscape approaches to conservation and development. Sustain. Sci. 12 (3), 465-476.

Schekkerman, H., Teunissen, W., Oosterveld, E., 2008. The effect of 'mosaic management' on the demography of black-tailed godwit Limosa limosa on farmland. J. Appl. Ecol. 45 (4), 1067-1075.

Scheper, J., Holzschuh, A., Kuussaari, M., Potts, S.G., Rundlof, M., Smith, H.G., Kleijn, D., 2013. Environmental factors driving the effectiveness of European agri-environmental measures in mitigating pollinator loss-a meta-analysis. Ecol. Lett. 16 (7), 912-920. 
Scheper, J., Bommarco, R., Holzschuh, A., Potts, S.G., Riedinger, V., Roberts, S.P.M., Rundlof, M., Smith, H.G., Steffan-Dewenter, I., Wickens, J.B., Wickens, V.J., Kleijn, D., 2015. Local and landscape-level floral resources explain effects of wildflower strips on wild bees across four European countries. J. Appl. Ecol. 52 (5), 1165-1175.

Schroder, J.J., Aarts, H.F.M., van Middelkoop, J.C., Schils, R.L.M., Velthof, G.L., Fraters, B., Willems, W.J., 2007. Permissible manure and fertilizer use in dairy farming systems on sandy soils in The Netherlands to comply with the Nitrates Directive target. Eur. J. Agron. 27 (1), 102-114.

Seibold, S., Gossner, M.M., Simons, N.K., Bluthgen, N., Muller, J., Ambarli, D., Ammer, C., Bauhus, J., Fischer, M., Habel, J.C., Linsenmair, K.E., Nauss, T., Penone, C., Prati, D., Schall, P., Schulze, E.D., Vogt, J., Wollauer, S., Weisser, W.W., 2019. Arthropod decline in grasslands and forests is associated with landscape-level drivers. Nature 574 (7780), 671-674.

Seto, K.C., Güneralp, B., Hutyra, L.R., 2012. Global forecasts of urban expansion to 2030 and direct impacts on biodiversity and carbon pools. Proc. Natl. Acad. Sci. U. S. A. 109 (40), 16083-16088.

Shackelford, G., Steward, P.R., Benton, T.G., Kunin, W.E., Potts, S.G., Biesmeijer, J.C., Sait, S.M., 2013. Comparison of pollinators and natural enemies: a meta-analysis of landscape and local effects on abundance and richness in crops. Biol. Rev. 88 (4), $1002-1021$.

Smart, J., Wotton, S.R., Dillon, I.A., Cooke, A.I., Diack, I., Drewitt, A.L., Grice, P.V., Gregory, R.D., 2014. Synergies between site protection and agri-environment schemes for the conservation of waders on lowland wet grasslands. Ibis 156 (3), 576-590.

Steffan-Dewenter, I., Munzenberg, U., Burger, C., Thies, C., Tscharntke, T., 2002. Scaledependent effects of landscape context on three pollinator guilds. Ecology 83 (5), $1421-1432$.

Steinger, T., Körner, C., Schmid, B., 1996. Long-term persistence in a changing climate: DNA analysis suggests very old ages of clones of alpine Carex curvula. Oecologia 105 (1), 94-99.

Stobbelaar, D.J., Janssen, W.J.T., Heide, C.M., Larenstein, H.V.H., 2018. Geïntegreerd natuur- en landschapsbeheer: succesfactoren voor het ontwikkelen van natuur en landschap. Van Hall Larenstein.

Sutherland, W.J., Pullin, A.S., Dolman, P.M., Knight, T.M., 2004. The need for evidencebased conservation. Trends Ecol. Evol. 19 (6), 305-308.

The Sustainable Finance Platform, 2020. Biodiversity Opportunities and Risks Forthe Financial Sector. The Sustainable Finance Platform. Working Group Biodiversity. URL https://www.dnb.nl/binaries/Biodiversity\%20opportunities\%20risks\%20for\% 20the\%20financial\%20sector_tcm46-389029.pdf. Last accessed: 17 June 2020.

Thomas, J.A., 2005. Monitoring change in the abundance and distribution of insects using butterflies and other indicator groups. Philos. Trans. R. Soc. Lond. B Biol. Sci. 360 (1454), 339-357.

Tilman, D., Clark, M., Williams, D.R., Kimmel, K., Polasky, S., Packer, C., 2017. Future threats to biodiversity and pathways to their prevention. Nature 546 (7656), 73-81.

Tittensor, D.P., Walpole, M., Hill, S.L.L., Boyce, D.G., Britten, G.L., Burgess, N.D., Butchart, S.H.M., Leadley, P.W., Regan, E.C., Alkemade, R., Baumung, R., Bellard, C., Bouwman, L., Bowles-Newark, N.J., Chenery, A.M., Cheung, W.W.L., Christensen, V., Cooper, H.D., Crowther, A.R., Dixon, M.J.R., Galli, A., Gaveau, V., Gregory, R.D., Gutierrez, N.L., Hirsch, T.L., Hoft, R., JanuchowskiHartley, S.R., Karmann, M., Krug, C.B., Leverington, F.J., Loh, J., Lojenga, R.K., Malsch, K., Marques, A., Morgan, D.H.W., Mumby, P.J., Newbold, T., NoonanMooney, K., Pagad, S.N., Parks, B.C., Pereira, H.M., Robertson, T., Rondinini, C., Santini, L., Scharlemann, J.P.W., Schindler, S., Sumaila, U.R., Teh, L.S.L., 
van Kolck, J., Visconti, P., Ye, Y.M., 2014. A mid-term analysis of progress toward international biodiversity targets. Science 346 (6206), 241-244.

Tscharntke, T., Tylianakis, J.M., Rand, T.A., Didham, R.K., Fahrig, L., Batary, P., Bengtsson, J., Clough, Y., Crist, T.O., Dormann, C.F., Ewers, R.M., Frund, J., Holt, R.D., Holzschuh, A., Klein, A.M., Kleijn, D., Kremen, C., Landis, D.A., Laurance, W., Lindenmayer, D., Scherber, C., Sodhi, N., Steffan-Dewenter, I., Thies, C., van der Putten, W.H., Westphal, C., 2012. Landscape moderation of biodiversity patterns and processes-eight hypotheses. Biol. Rev. 87 (3), 661-685.

Tschumi, M., Albrecht, M., Entling, M.H., Jacot, K., 2015. High effectiveness of tailored flower strips in reducing pests and crop plant damage. Proc. R. Soc. B Biol. Sci. 282 (1814), 189-196.

Tuck, S.L., Winqvist, C., Mota, F., Ahnstrom, J., Turnbull, L.A., Bengtsson, J., 2014. Landuse intensity and the effects of organic farming on biodiversity: a hierarchical metaanalysis. J. Appl. Ecol. 51 (3), 746-755.

Turner, R.K., Daily, G.C., 2008. The ecosystem services framework and natural capital conservation. Environ. Resource Econ. 39 (1), 25-35.

Van den Top, M., Van der Zouwen, M., 2002. Europees natuurbeleid in Nederland: een pionier die zichzelf in de weg loopt. Landschap 17, 81-96.

Van Laarhoven, G., Nijboer, J., Oerlemans, N., Piechocki, R., Pluimers, J., 2018. Biodiversity Monitor for the Dairy Sector. Rabobank, FrieslandCampina, Worldwide Fund for Nature, Netherlands. URL http://biodiversiteitsmonitormelkveehouderij.nl/ docs/Biodiversiteitsmonitor_engels.pdf.

Van Strien, A.J., Pannekoek, J., Gibbons, D.W., 2001. Indexing European bird population trends using results of national monitoring schemes: a trial of a new method. Bird Study 48, 200-213.

Van Turnhout, C.A.M., Foppen, R.P.B., Leuven, R., Siepel, H., Esselink, H., 2007. Scaledependent homogenization: changes in breeding bird diversity in the Netherlands over a 25-year period. Biol. Conserv. 134 (4), 505-516.

Van Vooren, L., Reubens, B., Broekx, S., Reheul, D., Verheyen, K., 2018. Assessing the impact of grassland management extensification in temperate areas on multiple ecosystem services and biodiversity. Agric. Ecosyst. Environ. 267, 201-212.

Vanbergen, A.J., et al., 2020. Transformation of agricultural landscapes in the Anthropocene: Nature's contributions to people, agriculture and food security. In: Bohan, D.A., Vanbergen, A.J. (Eds.), Advances in Ecological Research, 63, 193-253. Elsevier.

Vanden Broeck, A., Maes, D., Kelager, A., Wynhoff, I., WallisDeVries, M.F., Nash, D.R., Oostermeijer, J.G.B., Van Dyck, H., Mergeay, J., 2017. Gene flow and effective population sizes of the butterfly Maculinea alcon in a highly fragmented, anthropogenic landscape. Biol. Conserv. 209, 89-97.

Verhoeven, J.T.A., Beltman, B., Janssen, R., Soons, M.B., 2017. Delineating landscape-scale processes of hydrology and plant dispersal for species-rich fen conservation: the Operational Landscape Unit approach. Wetl. Ecol. Manag. 25 (6), 761-774.

Virkkala, R., Rajasarkka, A., Heikkinen, R.K., Kuusela, S., Leikola, N., Poyry, J., 2018. Birds in boreal protected areas shift northwards in the warming climate but show different rates of population decline. Biol. Conserv. 226, 271-279.

Vogels, J.J., Verberk, W., Lamers, L.P.M., Siepel, H., 2017. Can changes in soil biochemistry and plant stoichiometry explain loss of animal diversity of heathlands? Biol. Conserv. 212, 432-447.

Wamelink, G.W.W., de Knegt, B., Pouwels, R., Schuiling, C., Wegman, R.M.A., Schmidt, A.M., van Dobben, H.F., Sanders, M.E., 2013. Considerable environmental bottlenecks for species listed in the Habitats and Birds Directives in the Netherlands. Biol. Conserv. 165, 43-53. 
Warner, D., Tzilivakis, J., Green, A., Lewis, K., 2017. Prioritising agri-environment options for greenhouse gas mitigation. Int. J. Clim. Change Strategies Manage. 9 (1), 104-122.

Watling, J.I., Nowakowski, A.J., Donnelly, M.A., Orrock, J.L., 2011. Meta-analysis reveals the importance of matrix composition for animals in fragmented habitat. Glob. Ecol. Biogeogr. 20 (2), 209-217.

Whittingham, M.J., Krebs, J.R., Swetnam, R.D., Vickery, J.A., Wilson, J.D., Freckleton, R.P., 2007. Should conservation strategies consider spatial generality? Farmland birds show regional not national patterns of habitat association. Ecol. Lett. 10 (1), 25-35.

Wojcik, V.A., Buchmann, S., 2012. Pollinator conservation and management on electrical transmission and roadside rights-of-way: a review. J. Poll. Ecol. 7, 16-26.

WWF, 2016. Living Planet Report 2016. Risk and Resilience in a New Era. WWF International, Gland, Switzerland.

Xu, W.H., Xiao, Y., Zhang, J.J., Yang, W., Zhang, L., Hull, V., Wang, Z., Zheng, H., Liu, J.G., Polasky, S., Jiang, L., Xiao, Y., Shi, X.W., Rao, E.M., Lu, F., Wang, X.K., Daily, G.C., Ouyang, Z.Y., 2017. Strengthening protected areas for biodiversity and ecosystem services in China. Proc. Natl. Acad. Sci. U. S. A. 114 (7), 1601-1606. 